(2) Open Access Full Text Article

\title{
Burnout and Associated Factors Among Medical Students in a Public University in Uganda: A Cross-Sectional Study
}

This article was published in the following Dove Press journal:

Advances in Medical Education and Practice

Jonathan Kajjimu (D)'

Mark Mohan Kaggwa $\mathbb{D}^{2}$

Felix Bongomin (iD) ${ }^{3}$

'Faculty of Medicine, Mbarara University of Science and Technology, Mbarara, Uganda; ${ }^{2}$ Department of Psychiatry, Faculty of Medicine, Mbarara University of Science and Technology, Mbarara, Uganda; ${ }^{3}$ Department of Medical Microbiology and Immunology, Faculty of Medicine, Gulu University, Gulu, Uganda
Background: Burnout is a well-recognized phenomenon that may manifest with feelings of stress, fatigue, or exhaustion. It is a common and emerging problem among healthcare workers. Medical students may be at increased risk of burnout given the rigorous nature of their training. However, there is a paucity of data on the burden of burnout among medical students in Africa.

Aim: This study aimed to determine the prevalence of burnout, as assessed using the Maslach Burnout Inventory - Student Survey (MBI-SS) as well as factors associated with the development of burnout among students pursuing Bachelor of Medicine and Bachelor of Surgery $(\mathrm{MBChB})$ degrees at Mbarara University of Science and Technology (MUST), Uganda.

Methods: A single-centre, cross-sectional, online survey was conducted among MBChB students of MUST. Burnout was assessed using the Maslach Burnout Inventory - Student Survey (MBI-SS) tool. Bivariate analysis and backward stepwise logistic regression analysis were performed to assess possible associations between variables related to participants' demography, socioeconomic, personal, learning environment, outside school environment aspects and burnout prevalence scores.

Results: A total of 145 medical students, 102 (70.3\%) male, with a median (range) age of 23 (18-40) years were studied. A total of 135 students (93.1\%) presented with high levels of emotional exhaustion, 90 (62.1\%) students had low levels of professional efficacy scores and $141(97.2 \%)$ of the medical students had high levels of cynicism. Overall, $79(54.5 \%)$ students had burnout, as defined by the MBI-SS tool. Choosing MBChB willingly appears to be an independent predictor of burnout (Adjusted odds ratio: 7.2; 95\% CI: 1.4-36.9; $\mathrm{p}=0.018$ ).

Conclusion: More than one-half of medical students questioned at MUST do experience a degree of burnout. Preventative and interventional measures should be considered in the development of the medical curriculum.

Keywords: medical students, burnout, Maslach Burnout Inventory, mental health, wellbeing; Uganda

\section{Introduction}

Burnout is, according to the 11 revision of the International Classification of Diseases (ICD-11),

"A syndrome conceptualized as resulting from chronic workplace stress that has not been successfully managed. It's characterised by three dimensions: feelings of energy
Correspondence: Jonathan Kajjimu Faculty of Medicine, Mbarara University of Science and Technology, Mbarara, Uganda Tel +256759719384

Email jonathkebenz37@gmail.com
Advances in Medical Education and Practice 2021:12 63-75

mit your manuscript (c) (1) (ㅇ) 202I Kajjimu et al. This work is published and licensed by Dove Medical Press Limited. The full terms of this license are available at https://www.dovepress.com/terms. C. work you hereby accept the Terms. Non-commercial uses of the work are permitted without any further permission from Dove Medical Press Limited, provided the work is properly attributed. For permission for commercial use of this work, please see paragraphs 4.2 and 5 of our Terms (https://www.dovepress.com/terms.php). 
depletion or exhaustion; increased mental distance from one's job or feelings of negativism or cynicism related to one's job; and reduced personal efficacy. “1

Burnout is an increasingly recognised problem among medical professionals. ${ }^{2}$ Previous studies in medical students found $14.8-79.9 \%$ of them experience burnout during their medical training. ${ }^{3-7}$ Its prevalence has been found to increase with medical school academic progression ${ }^{8,9}$ but studies have suggested that by equipping medical students with evidence-based stress management approaches to their education, the incidence of burnout is reduced irrespective of their academic progression. ${ }^{32}$

In working-class healthcare professions, burnout has been linked majorly to job- or work-related chronic stress. In medical students, it is most likely related to personal factors such as mental health disorder, physical activity, personal financial satisfaction, high parental expectations, alcohol consumption, and smoking status or individual learning environment. ${ }^{1,10}$ A 2017 systematic review suggested that, on average, one medical student out of two suffered from burnout as defined by the ICD-11. Medical students from the Middle East and Oceania countries were found to have a higher prevalence of burnout than those from countries in other continents, with no African data available at the time of the review. ${ }^{11}$ Higher levels of stress coupled with poor coping strategies may be the major factors responsible for the development of burnout among medical students, ${ }^{3}$ due to the cyclic relation between stress and emotional exhaustion. ${ }^{12}$ Medical students, when compared to age-matched members of the general public, have been shown to have a poorer psychological quality of life. ${ }^{13}$ A 2015 systematic review showed that medical students displayed a variety of coping mechanisms for burnout such as personal engagement, extracurricular activities including mainly musical and physical activities, student autonomy, mentorship programs, evaluation systems, career counseling and life coaching. $^{3}$

The prevalence of burnout among medical students at Mbarara University of Science and Technology (MUST) was unknown. We sought to identify the degree of burnout and identify any causal factors such as learning environment, personal life factors and outside school life factors. This cross-sectional study aimed at investigating the prevalence and factors associated with burnout among medical students in their pre-clinical and clinical years of study at MUST.

\section{Materials and Methods}

\section{Study Design}

An online descriptive cross-sectional study was conducted between $6^{\text {th }}$ September 2020 until $20^{\text {th }}$ September 2020, using a Google form.

\section{Study Setting}

The study was carried out at Mbarara University of Science and Technology, commonly called Mbarara University. It is a public university accredited by the National Council for Higher Education, offering both undergraduate and postgraduate programs. MUST was established in 1989 and has two campuses - Kihumuro campus and Mbarara campus. The Faculty of Medicine is located at the Mbarara campus approximately 266 kilometers southwest of Kampala. The MBChB (Bachelor of Medicine and Bachelor of Surgery) program at Mbarara University takes 5 years. There were approximately 423 medical students enrolled for the 2019/2020 academic year in the Faculty of Medicine at MUST.

\section{Study Sample}

Undergraduate students from first to final years at MUST, pursing a medical program of Bachelor of Medicine and Bachelor of Surgery, were surveyed using an enrollment criteria including students being in the official WhatsApp groups of the respective class years and voluntarily consenting to take part in the study (see Figure 1). Representatives of each class were contacted by the principal investigator and informed about the study procedures, ethical issues and data collection. The participants were enrolled using a consecutive sampling technique. Students were recruited into the study through class representatives. The survey tool was then disseminated through class official WhatsApp groups. The inclusion criteria were medical students at MUST enrolled for the academic year 2019/2020. Other health profession students were not eligible for enrollment in this study.

The required sample size was calculated using the Kish-Leslie formula.

$$
N=\frac{Z^{2} p(1-p)}{d^{2}}
$$

where:

$N=$ Sample size

$Z=$ Standard deviation at 95\% Confidence Interval (1.960) 


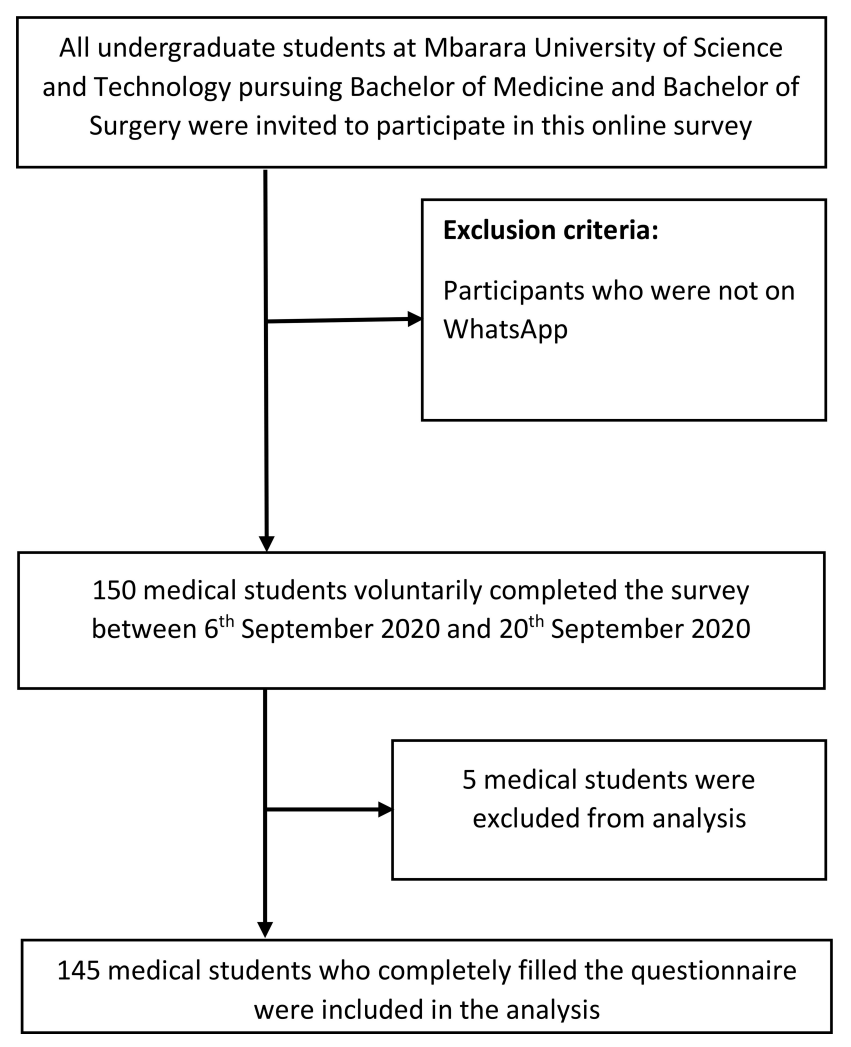

Figure I Flow chart for enrollment of participants.

$p=$ Expected prevalence of depression among medical students

$d=$ Precision of the estimate $(5 \%)$

The prevalence of burnout was taken to be an average of 0.5 since there had not been any previous study carried out at MUST. This point prevalence, of 50\% was also found in a recent study assessing burnout among medical students in Ethiopia. ${ }^{16}$

We used the modified Kish-Leslie equation ${ }^{33}$ to calculate the available sample size; where $K$ was the estimated overall population of the study population.

$$
n=\frac{N}{1+\frac{(N-1)}{K}}
$$

To cater for non-correspondents assuming a response rate of $90 \%$, a total of $10 \%$ of the sample size was added. This led to the required sample size of 229 students.

\section{Measurements}

We developed a questionnaire that would collect participants' characteristics (demography and socioeconomic factors) and their MBI-SS scores. We also asked about factors that might be associated with burnout among medical students. Participants' characteristics included sex, age, year of study, religious/spiritual affiliation, source of tuition funding, marital status, family income, agreement with the effectiveness of wellness initiatives at their institution, and family residence.

Burnout was assessed using the Maslach Burnout Inventory - Student Survey tool which was adapted from $^{17,18}$ and had been validated in Brazil. ${ }^{19}$ The MBS$\mathrm{SS}$ is a self-administered tool consisting of 15 questions. It is subdivided into three subscales: emotional exhaustion (five items), cynicism (four items), and professional efficacy (six items). All items are assessed by frequency using $\mathrm{aL}$ ikert scale ranging from never (0) to every day (6).

The tool has an internal consistency of each latent factor greater than 0.7 with values of $0.77,0.72$, and 0.81 for emotional exhaustion, professional efficacy, and cynicism, respectively. ${ }^{20} \mathrm{~A}$ test-retest reliability determined at about 4 weeks later, a yielded reliability coefficients of 89, 84 and 67 respectively for exhaustion, cynicism and academic efficacy. ${ }^{21}$ The sensitivity, specificity, positive and negative predictive values of the of the 15-item MBI-SS were 91.9\% (95\% CI $=82.5-96.5 \%)$, 93.2\% (95\% CI $=87.5-96.4 \%), 86.4 \%$ (95\% CI $=76.1-$ $92.7 \%)$ and $96.1 \%(95 \% \mathrm{CI}=91.2-98.3 \%)$ respectively. The positive and negative likelihood ratios were 13.48 (95\% CI $=7.15-25.44)$ and 0.09 (95\% CI $=0.04-0.20)$ respectively. $^{20}$

There are two validated calculation methods used to compare burnout scores among participants ie, the summation (SUM) and average (AVE) method. ${ }^{17}$ Burnout is determined by the total score of the MBI-SS based on the participant's responses by using both the tridimensional and bidimensional diagnostic criteria for burnout syndrome as listed in the ICD-11. On a two-dimensional model, it is identified by high scores on both emotional exhaustion and cynicism subscales. In the three-dimensional model, lowlevel burnout was determined based on the following scores: emotional exhaustion (0 - 9), cynicism (0 - 1), and professional efficacy $<27$. Moderate level burnout was determined based on the following scores: emotional exhaustion (10 - 14), cynicism (2 - 6), and professional efficacy (23 - 27). At a high level, burnout was identified based on the following scores: emotional exhaustion $>14$, cynicism $>6$, and professional efficacy $<23$. ${ }^{18}$ High scores on emotional exhaustion and cynicism with low scores on professional efficacy are indicative of burnout. ${ }^{20}$

Factors associated with burnout among medical students were adapted from Haile et al, ${ }^{16,18,22}$ and modified 
to suit the institution's low-income setting. Most responses were dichotomised.

The questionnaire was piloted by $23(10 \%$ of the sample size) Gulu University medical students. A Cronbach alpha of 0.8099 was obtained, demonstrating the high reliability of the tool in assessing the study outcomes.

\section{Data Analysis}

Data analyses were performed using StataCorp. 2019. Stata: Release 16. Statistical Software. College Station, TX: StataCorp LLC. Medical students' characteristics were summarized with proportions. The prevalence of burnout was determined from the total score of the MBISS tool using the tridimensional criteria based on the participants' responses to Likert scale questions related to emotional exhaustion, professional efficacy, and cynicism. Proportions were used to estimate the prevalence of burnout in the student sample. To quantify possible associations between the independent variable and dependent variables, we calculated crude odds ratios. Backward regression analysis was used to assess the predictive relationship between the associated factors obtained from the medical students and their respective burnout prevalence scores.

\section{Results}

\section{Participant Characteristics}

One hundred and fifty (35.5\%) responses were received. We removed one incomplete response and four duplicate responses, leaving behind 145 responses that were analysed (34.3\% response rate). The participants included 102 $(70.3 \%)$ male and 43 (29.7\%), female medical students. The majority $(49 \%, \mathrm{n}=71)$ of the students were under government sponsorship and over 90\% $(n=134)$ had a religious affiliation. The majority of the students were aged less than 24 years, and the rest of the sociodemographic characteristics were comparable across the 5 years of studies as shown in Table 1.

\section{Prevalence of Burnout Among Medical Students}

Table 2 presents the prevalence of burnout among medical students. More than half $(54.5 \%, \mathrm{n}=79)$ of the medical students fitted the definition of burnout using the tridimensional dimensional criteria. Of the 145 students, 93.1\% $(n=135)$ had high emotional exhaustion scores, $62.1 \%(n=90)$ had low professional efficacy scores and $97.2 \%(n=141)$ had high cynicism scores.

\section{Factors Associated with Burnout Among Medical Students}

In the unadjusted logistic regression analysis, several factors were found to be independently associated with burnout. These including factors intrinsic to the student such as being optimistic about their future career $(\mathrm{OR}=2.70,95 \%$ CI 1.11 to $6.55 ; \mathrm{p}=0.028)$, feeling fulfilled and happy at work $(\mathrm{OR}=2.77,95 \% \mathrm{CI} 1.31$ to $5.86 ; \mathrm{p}=0.008)$, willingly choosing to pursue $\mathrm{MBChB}(\mathrm{OR}=9.44,95 \%$ CI 2.04 to 43.58; $\mathrm{p}=0.004)$, feeling satisfied with medicine as their career choice $(\mathrm{OR}=5.07,95 \%$ CI 2.09 to $12.31 ; \mathrm{p}=0.000)$, feeling motivated with their studies $(\mathrm{OR}=2.43,95 \% \mathrm{CI}$ 1.08 to $5.45 ; \mathrm{p}=0.031$, and having ever developed any thoughts of dropping out of school $(\mathrm{OR}=0.17,95 \% \mathrm{CI}$ 0.06 to $0.48 ; \mathrm{p}=0.001$ ). Key factors, outside of the students locus included an exhaustive day-to-day routine of studies ( $\mathrm{OR}=0.43$, 95\% CI 0.19 to $0.96 ; \mathrm{p}=0.040)$, the challenge of commuting long distances $(\mathrm{OR}=0.30,95 \% \mathrm{CI} 0.13$ to $0.68 ; \mathrm{p}=0.004)$, insufficient leisure time $(\mathrm{OR}=2.2,95 \% \mathrm{CI}$ 1.12 to $4.30 ; \mathrm{p}=0.021$ ), and considering one's self important to their family member $(\mathrm{OR}=6.08,95 \%$ CI 1.27 to 29.22; $\mathrm{p}=0.024)$. More details in Table 3.

In multiple logistic backward regression only one factor, choosing $\mathrm{MBChB}$ willingly $(\mathrm{OR}=7.20,95 \% \mathrm{CI} 1.40$ to $36.93 ; \mathrm{p}=0.018$ ) was found to be independently associated with burnout. Table 4 contains more details.

\section{Discussion}

Our cross-sectional study looked at the prevalence of burnout among medical students at MUST, as well as possible associations. More than half of the students described burnout. Willingly choosing a career in medicine was the only identified associated factor. The high prevalence of burnout in our study is consistent with a similar study in Egypt which reported a burnout prevalence of $79.9 \%{ }^{7}$ One possible reason could be that medical students were unaware of the issue of burnout. A 2010 systematic review, suggested that there existed an association between a lower level of tolerance for uncertainty or ambiguity and self-reported burnout among medical students. $^{23}$ Studies conducted among medical students in Ethiopia and Spain found low levels of burnout, 34\% and $14.8 \%$, respectively. ${ }^{6,16}$ Such discrepancies in the burnout prevalence in various studies may be attributed to the 
Table I Participants' Characteristics

\begin{tabular}{|c|c|c|c|c|c|c|c|}
\hline Characteristics & $\begin{array}{l}\text { Year I } \\
(n=22)\end{array}$ & $\begin{array}{l}\text { Year } 2 \\
(n=28)\end{array}$ & $\begin{array}{l}\text { Year } 3 \\
(n=38)\end{array}$ & $\begin{array}{l}\text { Year } 4 \\
(n=26)\end{array}$ & $\begin{array}{l}\text { Year } 5 \\
(n=3 I)\end{array}$ & $\begin{array}{l}\text { Total } \\
N=\text { I } 45\end{array}$ & P-value \\
\hline $\begin{array}{l}\text { Sex, n (\%) } \\
\text { Male } \\
\text { Female }\end{array}$ & $\begin{array}{l}10(23.3) \\
10(22.2)\end{array}$ & $\begin{array}{l}8(18.6) \\
8(17.7)\end{array}$ & $\begin{array}{l}29(28.4) \\
9(20.9)\end{array}$ & $\begin{array}{l}20(19.6) \\
6(14.0)\end{array}$ & $\begin{array}{l}21(20.6) \\
10(23.3)\end{array}$ & $\begin{array}{l}102(70.3) \\
43(29.7)\end{array}$ & 0.414 \\
\hline $\begin{array}{l}\text { Age (years) } \\
\qquad \begin{array}{l}\text { I8-23 } \\
24-40\end{array}\end{array}$ & $\begin{array}{l}19(20.9) \\
3(5.6)\end{array}$ & $\begin{array}{l}25(27.5) \\
3(5.6)\end{array}$ & $\begin{array}{l}32(35.2) \\
6(11.1)\end{array}$ & $\begin{array}{l}8(8.8) \\
18(33.3)\end{array}$ & $\begin{array}{l}7(7.7) \\
24(44.4)\end{array}$ & $\begin{array}{l}91(62.8) \\
54(37.2)\end{array}$ & $0.000 *$ \\
\hline $\begin{array}{l}\text { Religious/spiritual affiliation n (\%) } \\
\text { Yes } \\
\text { No }\end{array}$ & $\begin{array}{l}22(16.4) \\
0\end{array}$ & $\begin{array}{l}26(19.4) \\
2(18.1)\end{array}$ & $\begin{array}{l}36(26.9) \\
2(18.1)\end{array}$ & $\begin{array}{l}24(17.9) \\
2(18.1)\end{array}$ & $\begin{array}{l}26(19.4) \\
5(45.5)\end{array}$ & $\begin{array}{l}\text { I } 34(92.4) \\
\text { II (7.6) }\end{array}$ & 0.255 \\
\hline $\begin{array}{l}\text { How is your tuition funded?, n (\%) } \\
\text { Government funded } \\
\text { NGO funded } \\
\text { Private funded } \\
\text { Self-funded }\end{array}$ & $\begin{array}{l}11(15.5) \\
0 \\
10(18.2) \\
1(9.1)\end{array}$ & $\begin{array}{l}12(16.9) \\
2(25.0) \\
8(14.6) \\
6(54.6)\end{array}$ & $\begin{array}{l}2 \mid(29.6) \\
\text { I }(12.5) \\
14(25.5) \\
2(18.2)\end{array}$ & $\begin{array}{l}15(21.1) \\
3(37.5) \\
6(10.9) \\
2(18.2)\end{array}$ & $\begin{array}{l}12(16.9) \\
2(25.0) \\
17(30.9) \\
0\end{array}$ & $\begin{array}{l}71(49.0) \\
8(5.5) \\
55(37.9) \\
I I(7.6)\end{array}$ & 0.066 \\
\hline $\begin{array}{l}\text { Relationship status, } \mathrm{n}(\%) \\
\text { Married } \\
\text { In a relationship with a steady partner } \\
\text { In a relationship without a steady partner } \\
\text { Single }\end{array}$ & $\begin{array}{l}\text { I }(20.0) \\
3(11.1) \\
I(16.7) \\
17(15.9)\end{array}$ & $\begin{array}{l}2(40.0) \\
2(7.4) \\
I(16.7) \\
23(21.5)\end{array}$ & $\begin{array}{l}\text { I (20.0) } \\
9(33.3) \\
2(33.3) \\
26(24.3)\end{array}$ & $\begin{array}{l}\text { I (20.0) } \\
4(14.8) \\
\text { I }(16.7) \\
20(18.7)\end{array}$ & $\begin{array}{l}0 \\
9(33.3) \\
1(16.7) \\
21(19.6)\end{array}$ & $\begin{array}{l}5(3.5) \\
27(18.6) \\
6(4.1) \\
107(73.8)\end{array}$ & 0.790 \\
\hline $\begin{array}{l}\text { How is your family income wage (minimum } \\
\text { wage)?, n (\%) } \\
\text { Unsatisfactory } \\
\text { Satisfactory }\end{array}$ & $\begin{array}{l}15(19.7) \\
7(10.1)\end{array}$ & $\begin{array}{l}18(23.7) \\
10(14.5)\end{array}$ & $\begin{array}{l}15(19.7) \\
23(33.3)\end{array}$ & $\begin{array}{l}\text { II (I4.5) } \\
\text { I5 (2I.7) }\end{array}$ & $\begin{array}{l}\text { I7 (22.4) } \\
\text { I4 (20.3) }\end{array}$ & $\begin{array}{l}76(52.4) \\
69(47.6)\end{array}$ & 0.113 \\
\hline $\begin{array}{l}\text { How would you gage wellness initiatives at your } \\
\text { institution?, n (\%) } \\
\text { Not effective } \\
\text { Effective }\end{array}$ & $\begin{array}{l}\text { I3 (I3.4) } \\
9(18.8)\end{array}$ & $\begin{array}{l}19(19.6) \\
9(18.8)\end{array}$ & $\begin{array}{l}24(24.7) \\
14(29.7)\end{array}$ & $\begin{array}{l}17(17.5) \\
9(18.8)\end{array}$ & $\begin{array}{l}24(24.7) \\
7(14.6)\end{array}$ & $\begin{array}{l}97(66.9) \\
48(33.1)\end{array}$ & 0.657 \\
\hline $\begin{array}{l}\text { What's your family residence?, n(\%) } \\
\text { Urban } \\
\text { Rural }\end{array}$ & $\begin{array}{l}14(15.1) \\
8(15.4)\end{array}$ & $\begin{array}{l}\text { I7 (I8.3) } \\
\text { II (2I.2) }\end{array}$ & $\begin{array}{l}23(24.7) \\
15(28.9)\end{array}$ & $\begin{array}{l}16(17.2) \\
10(19.2)\end{array}$ & $\begin{array}{l}23(24.7) \\
8(15.4)\end{array}$ & $\begin{array}{l}93(64.1) \\
52(35.9)\end{array}$ & 0.773 \\
\hline
\end{tabular}

Note: *Bolded to represent a significant p-value.

different burnout measurement tools used. Additionally, students in different countries are exposed to different socio-economic, political, health, and conflict-related stress factors. ${ }^{3}$

Burnout was higher among males (70.9\%) compared to females (29.1\%), a consistent finding with a systematic review that found male medical students to have a higher burnout prevalence. ${ }^{15}$ This could be due to the many male medical student participants as indicated in most studies. However, whether these many male survey responders are a true representative of their various institutions' male medical student population, remains a question to answer to come up with a conclusive finding. It has been proposed, by some, that female medical students are at a high risk of burnout than their male counterparts. ${ }^{14}$ Female students are more likely to suffer from stress factors than male medical students, ${ }^{4}$ with more demands placed on them outside of the university. ${ }^{8}$

Third and fourth-year medical students had the highest level of burnout in this study. This correlates with prior studies that showed a higher degree of burnout in senior medical students. ${ }^{16,17}$ The transition from preclinical years to clinical years of training appears to be a risk factor for 
Table 2 Prevalence of Burnout Among Medical Students

\begin{tabular}{|l|l|l|}
\hline & $\mathbf{n}=\mathbf{1 4 5}$ & $\%$ \\
\hline Burnout prevalence, subscales and levels with scores* & 79 & 54.5 \\
\hline $\begin{array}{l}\text { Emotional Exhaustion } \\
\text { Low (0-9) }\end{array}$ & 0 & \\
Moderate (10-14) & 10 & 0 \\
High >14 & 135 & 9.9 \\
\hline Professional Efficacy & & \\
Low >27 & 42 & 29.0 \\
Moderate (23-27) & 13 & 9.0 \\
High <23 & 90 & 62.1 \\
\hline Cynicism & & \\
Low (0-I) & 0 & 0 \\
Moderate (2-6) & 4 & 2.8 \\
High >6 & 141 & 97.2 \\
\hline
\end{tabular}

Note: *Scores based on Ef et al. ${ }^{18}$

academic stress in medical school. ${ }^{5,24}$ The low burnout prevalence of fifth years may be due to them having learned some coping strategies such as life coaching, reflective practice, self-care, musical and physical activities.

One interesting finding in our study was that willingly choosing to undertake $\mathrm{MBChB}$ was found to be significantly associated with an increased risk of burnout. This is contrary to a Cameroonian study that reported that students who regretted choosing their medical studies had higher burnout scores than their peers. ${ }^{25}$ Medical schools in countries like America have established wellness programs that could be adapted to address the "bio-psychosocial-spiritual burnout" epidemic among medical students. ${ }^{23,26}$ In Australasia, several wellness initiatives have been trialed. These include the integration of a wellbeing curriculum alongside the traditional medical curriculum such as the SAFE-DRS program at the University of Auckland ${ }^{30}$ and the Health Enhancement Program at Monash University Medical School. ${ }^{31}$ A U.S based study evaluating the success of a student-led program teaching stress management and self-care skills to first-year medical students, found it to be helpful (based on longevity, student participation, and student feedback). ${ }^{27}$ Additionally, the GMC - UK has provided guidance to medical schools on the creation of peer support networks, group sessions on stress management, and mentoring schemes. $^{29}$

Medical schools promote competition rather than cooperation. Training-related stress factors including annual examinations, an inability to cope with academic demands, and pressure with an obligation to succeed all compound the problem. Additionally, a sense of helplessness coupled with sleep deprivation, financial challenges, and the emotional burden of witnessed suffering stress medical students. ${ }^{5,24}$ Other studies have found associations between burnout in medical students with not seeing coursework as a source of pleasure, feeling uncomfortable with course activities, not acquiring skills necessary to become a doctor, poor social support, being less than satisfied with the education system, selfperception of health, optimism, and motivation in studies. ${ }^{16,18,22}$ Our study did not find any such associations.

Burnout is not only harmful to the medical students, their relatives, medical schools, and peers but to also the patients they care for. There is thus a heightened need to address burnout among medical students to ensure that delivery of compassionate patient care is kept paramount. ${ }^{4,5,28}$

\section{Limitations}

Our study had several limitations. First, this was a cross-sectional study. It could not allow us to study the variation of burnout among medical students throughout their entire 5-year study period in medical school at MUST. Second, the small response rate might have led to a type 2 error. Census involving these students would reveal more reliable findings. Recall bias may also have occurred amongst students since, by the time the study was conducted, students were offcampus due to the cessation of educational activities due to the COVID-19 pandemic. This, in itself, may have also contributed.

\section{Implications}

Our study findings should be generalizable to many other low- and middle-income countries. We used a standardised burnout measurement tool to increase the reliability and validity of our study findings. This has been the first study to be conducted among medical students in Uganda and it has revealed high levels of emotional exhaustion, cynicism, and low levels of professional efficacy. There needs to be an investment in the provision of mental health support to medical students through interventions to raise awareness, understanding, and prevention of the development of psychological distress, burnout, and mental health disorders like depression and anxiety among medical students. The efficacy 
Table 3 Distribution of MUST Medical Students According to Variables Related to Participant Characteristics, Personal Aspects, Learning Environment, Outside School Environment and Prevalence of Burnout

\begin{tabular}{|c|c|c|c|c|}
\hline Variables & n (\%) & Burnout (\%) & Crude OR (Cl 95\%) & P-value \\
\hline All responses $(n=145)$ & $79(100.0)$ & 54.5 & & \\
\hline \multicolumn{5}{|l|}{ Sex } \\
\hline Male $(n=102)$ & $56(54.9)$ & 70.9 & $1.06(0.52-2.16)$ & 0.876 \\
\hline Female $(n=43)$ & $23(53.5)$ & 29.1 & 1 & \\
\hline \multicolumn{5}{|l|}{ Age (years) } \\
\hline $18-23(n=91)$ & $51(56.0)$ & 64.6 & 1 & \\
\hline $23-40(n=54)$ & $28(51.9)$ & 35.4 & $0.84(0.43-1.66)$ & 0.624 \\
\hline \multicolumn{5}{|l|}{ Year of study } \\
\hline Year I $(n=22)$ & $14(63.6)$ & 17.7 & 1 & \\
\hline Year $2(n=28)$ & $14(50.0)$ & 17.7 & $0.57(0.18-1.79)$ & 0.337 \\
\hline Year $3(n=38)$ & $24(63.2)$ & 30.4 & $0.98(0.33-2.91)$ & 0.970 \\
\hline Year $4(n=26)$ & I5 (57.7) & 19.0 & $0.78(0.24-2.50)$ & 0.675 \\
\hline Year $5(n=31)$ & $12(38.7)$ & 15.2 & $0.36(0.12-1.12)$ & 0.077 \\
\hline \multicolumn{5}{|l|}{ Religion/spiritual affiliation } \\
\hline Yes $(n=134)$ & $73(54.5)$ & 92.4 & I (0.29-3.43) & 0.997 \\
\hline No $(n=11)$ & $6(54.6)$ & 7.6 & 1 & \\
\hline \multicolumn{5}{|l|}{ Tuition funding } \\
\hline Government funded $(n=7 I)$ & $38(53.5)$ & 48.1 & 1 & \\
\hline NGO funded $(n=8)$ & $3(37.5)$ & 3.8 & $0.52(0.12-2.35)$ & 0.396 \\
\hline Private funded $(n=54)$ & $30(55.6)$ & 38.0 & $1.09(0.53-2.21)$ & 0.821 \\
\hline Self-funded $(n=12)$ & $8(66.7)$ & 10.1 & $1.74(0.48-6.29)$ & 0.401 \\
\hline \multicolumn{5}{|l|}{ Marital status } \\
\hline Married $(n=5)$ & $4(80.0)$ & 5.1 & $5(0.49-50.83)$ & 0.174 \\
\hline In a relationship with a steady partner $(n=27)$ & $12(44.4)$ & 15.2 & 1 & \\
\hline In a relationship without a steady partner $(n=6)$ & $3(50.0)$ & 3.8 & $\mathrm{I} .25(0.2 \mathrm{I}-7.35)$ & 0.805 \\
\hline Single $(n=107)$ & $60(56.1)$ & 76.0 & $1.60(0.68-3.73)$ & 0.281 \\
\hline \multicolumn{5}{|l|}{ Family Income } \\
\hline Unsatisfactory $(n=76)$ & $36(47.4)$ & 45.6 & 1 & \\
\hline Satisfactory $(n=69)$ & $43(62.3)$ & 54.4 & $1.84(0.95-3.57)$ & 0.072 \\
\hline \multicolumn{5}{|l|}{ Effectiveness wellness initiatives } \\
\hline Not effective $(n=97)$ & $55(56.7)$ & 69.6 & 1 & \\
\hline Effective $(n=48)$ & $24(50.0)$ & 30.4 & $0.76(0.38-1.53)$ & 0.446 \\
\hline \multicolumn{5}{|l|}{ Family residence } \\
\hline Rural $(n=52)$ & $29(55.8)$ & 36.7 & $1.08(0.54-2.15)$ & 0.816 \\
\hline Urban $(n=93)$ & $50(53.8)$ & 63.3 & I & \\
\hline \multicolumn{5}{|l|}{ What's your health self-perception? } \\
\hline $\operatorname{Bad}(n=14)$ & $8(57.1)$ & 10.1 & 1 & \\
\hline Good $(n=|3|)$ & $7 \mid(54.2)$ & 89.9 & $0.89(0.29-2.70)$ & 0.834 \\
\hline \multicolumn{5}{|l|}{ How do you consider yourself emotionally? } \\
\hline Calm $(n=119)$ & $68(57.1)$ & 86.1 & $1.82(0.77-4.29)$ & 0.172 \\
\hline Tense $(n=26)$ & II (42.3) & 13.9 & 1 & \\
\hline \multicolumn{5}{|l|}{ Have you had any mental disorder with prior diagnosis by a psychiatrist? } \\
\hline Yes $(n=3)$ & $2(66.7)$ & 2.5 & $1.69(0.15-19.04)$ & 0.672 \\
\hline No $(n=142)$ & $77(54.2)$ & 97.5 & 1 & \\
\hline
\end{tabular}

(Continued) 
Table 3 (Continued).

\begin{tabular}{|c|c|c|c|c|}
\hline Variables & n (\%) & Burnout (\%) & Crude OR (Cl 95\%) & P-value \\
\hline \multicolumn{5}{|l|}{ Do you have regular WHO recommended physical activity? } \\
\hline Yes $(n=54)$ & $33(61.1)$ & 41.8 & $1.54(0.78-3.05)$ & 0.218 \\
\hline No $(n=91)$ & $46(50.6)$ & 58.2 & 1 & \\
\hline \multicolumn{5}{|l|}{ Do you have optimism in the future of medicine as your career? } \\
\hline Not optimistic $(n=26)$ & $9(34.6)$ & 11.4 & I & \\
\hline Optimistic $(n=119)$ & $70(58.8)$ & 88.6 & $2.70(1.11-6.55)$ & 0.028 \\
\hline \multicolumn{5}{|l|}{ What's your personal financial satisfaction? } \\
\hline Dissatisfied $(n=114)$ & $58(50.9)$ & 73.4 & I & \\
\hline Satisfied $(n=31)$ & $21(67.7)$ & 26.6 & $2.07(0.88-4.69)$ & 0.098 \\
\hline \multicolumn{5}{|l|}{ Do you have fulfillment and happiness as a medical student at your institution? } \\
\hline No $(n=4 I)$ & $15(36.7)$ & 19.0 & 1 & \\
\hline Yes $(n=104)$ & $64(61.5)$ & 81.0 & $2.77(1.31-5.86)$ & 0.008 \\
\hline \multicolumn{5}{|l|}{ Do you have parents who are doctors? } \\
\hline No $(n=139)$ & $76(54.7)$ & 96.2 & 1 & \\
\hline Yes $(n=6)$ & $3(50.0)$ & 3.8 & $0.83(0.16-4.25)$ & 0.822 \\
\hline \multicolumn{5}{|l|}{ Do you have high parent expectations? } \\
\hline Yes $(n=119)$ & $65(54.6)$ & 82.3 & $1.03(0.44-2.42)$ & 0.943 \\
\hline No $(n=26)$ & $14(53.9)$ & 17.7 & 1 & \\
\hline \multicolumn{5}{|l|}{ Do you use any substances like marijuana, shisha, cocaine etc? } \\
\hline Yes $(n=8)$ & $4(50.0)$ & 5.1 & $0.83(0.20-3.44)$ & 0.794 \\
\hline No $(n=137)$ & $75(54.7)$ & 94.9 & I & \\
\hline \multicolumn{5}{|l|}{ How is your alcohol consumption? } \\
\hline Low $(n=43)$ & $26(60.5)$ & 32.9 & $0.76(0.06-9.10)$ & 0.832 \\
\hline Moderate $(n=15)$ & $10(66.7)$ & 12.7 & I (0.07-13.87) & 1 \\
\hline High $(n=3)$ & $2(66.7)$ & 2.53 & I & \\
\hline $\begin{array}{l}\text { I do not consume alcohol and I have never thought of considering it before } \\
(n=69)\end{array}$ & $33(47.8)$ & 41.8 & $0.46(0.04-5.29)$ & 0.532 \\
\hline $\begin{array}{l}\text { I do not consume alcohol but I have ever thought of considering it before } \\
\text { due to stress. }(n=15)\end{array}$ & $8(53.3)$ & 10.1 & $0.57(0.42-7.74)$ & 0.674 \\
\hline \multicolumn{5}{|l|}{ What's your smoking status? } \\
\hline Never smoked and never thought of trying it out $(n=128)$ & $68(53.1)$ & 86.1 & $0.76(0.12-4.68)$ & 0.763 \\
\hline Current smoker $(n=5)$ & $3(60.0)$ & 3.8 & 1 & \\
\hline Former smoker $(n=3)$ & $3(100.0)$ & 3.8 & 1 & Omitted* \\
\hline Never smoked but I have thought of trying it out due to stress $(n=9)$ & $5(55.6)$ & 6.3 & $0.83(0.09-7.68)$ & 0.872 \\
\hline \multicolumn{5}{|l|}{ How are your school activities? } \\
\hline Studies and extracurricular $(n=110)$ & $64(58.2)$ & 81 & $1.86(0.86-4.00)$ & 0.115 \\
\hline Studies alone $(n=35)$ & $15(42.9)$ & 19 & 1 & \\
\hline \multicolumn{5}{|l|}{ Did you choose MBChB willingly? } \\
\hline No $(n=15)$ & $2(13.3)$ & 2.5 & 1 & \\
\hline Yes $(n=130)$ & $77(59.2)$ & 97.5 & $9.44(2.04-43.58)$ & 0.004 \\
\hline \multicolumn{5}{|l|}{ What are your average hours at school per day? } \\
\hline Up to 12 hours $(n=84)$ & $49(58.3)$ & 62 & 1 & \\
\hline More than 12 hours $(n=6 I)$ & $30(49.2)$ & 38 & $0.69(0.35-1.34)$ & 0.275 \\
\hline
\end{tabular}

(Continued) 
Table 3 (Continued).

\begin{tabular}{|c|c|c|c|c|}
\hline Variables & n (\%) & Burnout (\%) & Crude OR (Cl 95\%) & P-value \\
\hline \multicolumn{5}{|l|}{ Do you feel you have study overload and academic pressure? } \\
\hline Yes $(n=122)$ & $63(51.6)$ & 79.75 & $0.47(0.18-1.21)$ & 0.119 \\
\hline No $(n=23)$ & $16(69.6)$ & 20.25 & 1 & \\
\hline \multicolumn{5}{|l|}{ Are you satisfied with your medicine career choice? } \\
\hline Yes $(n=113)$ & $71(62.8)$ & 89.9 & $5.07(2.09-12.31)$ & 0.000 \\
\hline No $(n=32)$ & $8(25.0)$ & 10.1 & 1 & \\
\hline \multicolumn{5}{|l|}{ Do you feel motivated for your studies? } \\
\hline No $(n=32)$ & $12(37.5)$ & 15.2 & I & \\
\hline Yes $(n=113)$ & $67(59.5)$ & 84.8 & $2.43(1.08-5.45)$ & 0.031 \\
\hline \multicolumn{5}{|l|}{ Do you consider yourself important to your colleagues? } \\
\hline No $(n=18)$ & 7 (38.9) & 8.9 & 1 & \\
\hline Yes $(n=127)$ & $72(56.7)$ & 91.1 & $2.06(0.75-5.65)$ & 0.162 \\
\hline \multicolumn{5}{|l|}{ How is the routine of your studies? } \\
\hline Exhaustive $(n=109)$ & $54(49.5)$ & 68.4 & $0.43(0.19-0.96)$ & 0.040 \\
\hline Not exhaustive $(n=36)$ & $25(69.4)$ & 31.7 & I & \\
\hline \multicolumn{5}{|l|}{ Do you feel satisfied as a student with your institution's teaching strategies? } \\
\hline No $(n=53)$ & $31(58.5)$ & 39.2 & 1 & \\
\hline Yes $(n=92)$ & $48(52.2)$ & 60.8 & $0.77(0.39-1.53)$ & 0.462 \\
\hline \multicolumn{5}{|l|}{ Have you experienced any humiliation in your studies before? } \\
\hline Yes $(n=85)$ & $43(50.6)$ & 54.4 & $0.68(0.35-1.33)$ & 0.263 \\
\hline No $(n=60)$ & $36(60.0)$ & 45.6 & I & \\
\hline \multicolumn{5}{|l|}{ Have you ever developed any thoughts of dropping out of school? } \\
\hline Yes $(n=24)$ & $5(20.8)$ & 6.3 & $0.17(0.06-0.48)$ & 0.001 \\
\hline No $(n=|2|)$ & $74(6 \mid .2)$ & 93.7 & I & \\
\hline \multicolumn{5}{|l|}{ Do you feel you are acquiring skills necessary to become a doctor? } \\
\hline No $(n=9)$ & $2(22.2)$ & 2.5 & I & \\
\hline Yes $(n=136)$ & $77(56.6)$ & 97.5 & $4.57(0.92-22.8)$ & 0.064 \\
\hline \multicolumn{5}{|l|}{ What are your feelings about your course activities? } \\
\hline Comfortable $(n=114)$ & $65(57)$ & 82.3 & $1.61(0.73-3.58)$ & 0.242 \\
\hline Uncomfortable $(n=31)$ & $14(45.2)$ & 17.7 & 1 & \\
\hline \multicolumn{5}{|l|}{ Do you see coursework as a source of pleasure? } \\
\hline No $(n=101)$ & $53(52.5)$ & 67.1 & 1 & \\
\hline Yes $(n=44)$ & $26(59.1)$ & 32.9 & $1.31(0.64-2.68)$ & 0.463 \\
\hline \multicolumn{5}{|l|}{$\begin{array}{l}\text { What's your experience of searching for mental health support before at your } \\
\text { institution? }\end{array}$} \\
\hline Good and satisfied $(n=10)$ & $6(60.0)$ & 7.6 & 1 & \\
\hline Unsatisfied $(n=5)$ & I (20.0) & 1.3 & $0.17(0.01-2.09)$ & 0.165 \\
\hline $\begin{array}{l}\text { Never searched for mental health support in spite of having mental health } \\
\text { challenges }(n=40)\end{array}$ & $20(50.0)$ & 25.3 & $0.67(0.16-2.73)$ & 0.573 \\
\hline $\begin{array}{l}\text { Never searched for mental health support and never had mental health } \\
\text { challenges }(n=90)\end{array}$ & $52(57.8)$ & 65.8 & $0.91(0.24-3.46)$ & 0.893 \\
\hline \multicolumn{5}{|l|}{ Do you have any fears of hurting or harming patients? } \\
\hline No $(n=65)$ & $35(53.9)$ & 44.3 & I & \\
\hline Yes $(n=80)$ & $44(55.0)$ & 55.7 & $1.05(0.54-2.02)$ & 0.890 \\
\hline
\end{tabular}

(Continued) 
Table 3 (Continued).

\begin{tabular}{|c|c|c|c|c|}
\hline Variables & n (\%) & Burnout (\%) & Crude OR (Cl 95\%) & P-value \\
\hline \multicolumn{5}{|c|}{ Are you in academic competition with your colleagues? } \\
\hline Yes $(n=30)$ & $17(56.7)$ & 21.5 & $1.12(0.50-2.5 \mathrm{I})$ & 0.787 \\
\hline No $(n=115)$ & $62(53.9)$ & 78.5 & 1 & \\
\hline \multicolumn{5}{|c|}{ Do you have fear of being infected in hospital? } \\
\hline Yes $(n=108)$ & $55(50.9)$ & 69.6 & $0.56(0.26-1.22)$ & 0.144 \\
\hline No $(n=37)$ & $24(64.9)$ & 30.4 & I & \\
\hline \multicolumn{5}{|c|}{ Do you feel you have limited medical training time? } \\
\hline Yes $(n=7 I)$ & $40(56.3)$ & 50.6 & $1.16(0.60-2.23)$ & 0.660 \\
\hline No $(n=74)$ & $39(52.7)$ & 49.4 & & \\
\hline \multicolumn{5}{|c|}{ Do you have inability of answering academic patient questions? } \\
\hline Yes $(n=49)$ & $25(51.0)$ & 31.65 & $0.8 I(0.4 I-1.62)$ & 0.550 \\
\hline No $(n=96)$ & $54(56.3)$ & 68.35 & 1 & \\
\hline \multicolumn{5}{|c|}{ Do you have a positive influence of a religious/spiritual life in your studies? } \\
\hline No $(n=31)$ & $15(48.4)$ & 19 & $\mathrm{I}$ & \\
\hline Yes $(n=114)$ & $64(56.1)$ & 81 & $1.37(0.62-3.03)$ & 0.443 \\
\hline \multicolumn{5}{|c|}{ Do you have any financial challenges at school which bother you in your studies? } \\
\hline Yes $(n=79)$ & $39(49.4)$ & 49.4 & $0.63(0.33-1.23)$ & 0.177 \\
\hline No $(n=66)$ & $40(60.6)$ & 50.6 & I & \\
\hline \multicolumn{5}{|c|}{$\begin{array}{l}\text { Does the distance between campus or hospital and your place of residence/ } \\
\text { hostel inconvenience you at all? }\end{array}$} \\
\hline Yes $(n=34)$ & II (32.4) & 13.9 & $0.30(0.13-0.68)$ & 0.004 \\
\hline No $(n=1 I I)$ & $68(61.3)$ & 86.1 & 1 & \\
\hline \multicolumn{5}{|c|}{ Do you have frequent family meetings that you attend? } \\
\hline No $(n=130)$ & $71(54.6)$ & 89.9 & $\mathrm{I}$ & \\
\hline Yes $(n=15)$ & $8(53.3)$ & 10.1 & $0.95(0.33-2.77)$ & 0.925 \\
\hline \multicolumn{5}{|c|}{ Do you get sufficient leisure time? } \\
\hline No $(n=77)$ & $35(45.5)$ & 44.3 & $2.2(1.12-4.30)$ & 0.021 \\
\hline Yes $(n=68)$ & $44(64.7)$ & 55.7 & 1 & \\
\hline \multicolumn{5}{|c|}{ Do you consider yourself important to your family members? } \\
\hline No $(n=11)$ & $2(18.2)$ & 2.5 & 1 & \\
\hline Yes $(n=134)$ & $77(57.5)$ & 97.5 & $6.08(1.27-29.22)$ & 0.024 \\
\hline \multicolumn{5}{|c|}{$\begin{array}{l}\text { Have you lost any close family member(s) during your time in medical school } \\
\text { whose death affected you negatively in your studies? }\end{array}$} \\
\hline Yes $(n=28)$ & $17(60.7)$ & 21.5 & $1.37(0.59-3.18)$ & 0.462 \\
\hline No $(n=117)$ & $62(53.0)$ & 78.5 & I & \\
\hline \multicolumn{5}{|c|}{$\begin{array}{l}\text { Do you have any close family member(s) battling with a chronic disease } \\
\text { currently, whose condition you think may have negatively affected or is } \\
\text { negatively affecting your studies? }\end{array}$} \\
\hline Yes $(n=33)$ & $13(39.4)$ & 16.5 & $0.45(0.21-1.00)$ & 0.050 \\
\hline No $(n=112)$ & $66(58.9)$ & 83.5 & I & \\
\hline \multicolumn{5}{|c|}{$\begin{array}{l}\text { How often do you seek for social support when encountered with emotional } \\
\text { challenges? }\end{array}$} \\
\hline Not often $(n=113)$ & $57(50.4)$ & 72.15 & I & \\
\hline Often $(n=32)$ & $22(68.8)$ & 27.85 & $2.16(0.94-4.97)$ & 0.070 \\
\hline
\end{tabular}


Table 3 (Continued).

\begin{tabular}{|c|c|c|c|c|}
\hline Variables & n (\%) & Burnout (\%) & Crude OR (Cl 95\%) & P-value \\
\hline \multicolumn{5}{|c|}{ Do you have any personal relationship challenges? } \\
\hline Yes $(n=35)$ & $18(51.4)$ & 22.8 & $0.99(0.42-2.30)$ & 0.974 \\
\hline No $(n=56)$ & $29(51.8)$ & 36.7 & 1 & \\
\hline Not in a relationship $(n=54)$ & $32(59.3)$ & 40.5 & $1.35(0.64-2.88)$ & 0.431 \\
\hline \multicolumn{5}{|c|}{ Do you have additional family responsibilities? } \\
\hline Yes $(n=54)$ & $28(51.9)$ & 35.4 & $0.85(0.43-1.66)$ & 0.624 \\
\hline No $(n=91)$ & $51(56.0)$ & 64.6 & 1 & \\
\hline
\end{tabular}

Notes: Bolded to represent a significant p-value. *Omitted represents a p-value that could not be calculated due to having less than 5 observations.

Table 4 Outcome of Logistic Regression Analysis for Related Variables and Burnout in Medical Students

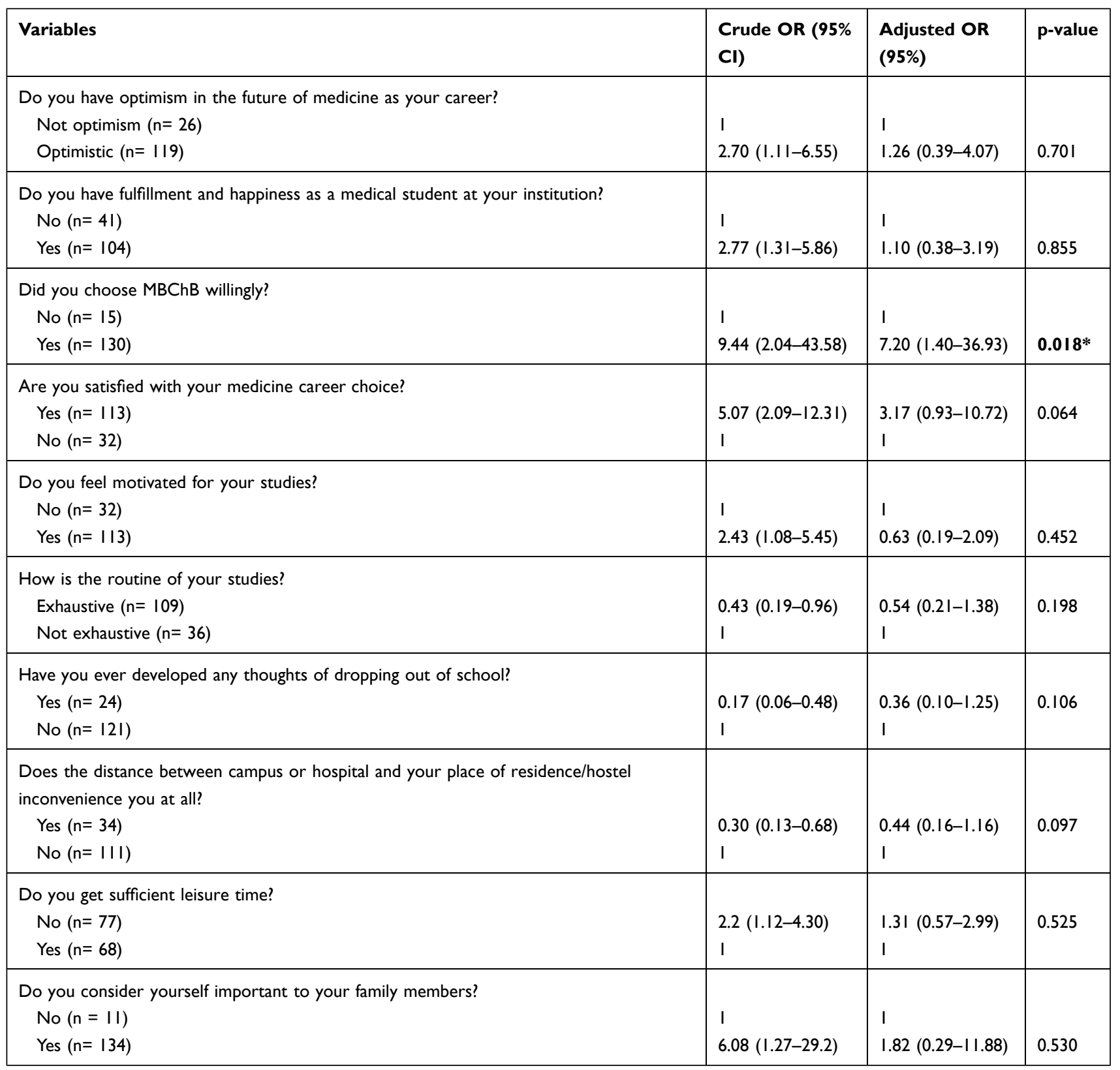

Note: *Bolded to represent a significant p-value. 
of this study could be measured by conducting a multi-centre, prospective longitudinal study.

Some student life activities may be present at MUST but these activities are not united under a comprehensive wellness objective. We hope that this study will help drive the establishment of wellbeing interventions at MUST.

\section{Data Sharing Statement}

Data are available upon reasonable request from the first author.

\section{Ethics Approval}

The study was performed in accordance with the international ethical standards of the Declaration of Helsinki. This study was approved by the Mbarara University of Science and Technology Research Ethics Committee (Approval number: 19/07-20). We also sought administrative approval from the dean of the Faculty of Medicine at Mbarara University of Science and Technology.

The participant's email and name were requested optionally for entering the participants into a raffle for participatory gift certificates as an incentive for completing the survey. Each study participant who opted to submit their details for enrollment into the raffle was assigned a random number, after which we randomly chose five study participants from the enrolled participants based on those random numbers.

\section{Acknowledgments}

We thank all participants for their willingness and the time they took to participate in the study. We thank the following students for serving as class representatives who reached out to their classmates with study link messages during the data collection stage including Viola Nansimbe, Innocent Arinaitwe, Ruth Nakawungu, Janat Nakachwa, Jeremiah Habizana, Taremwa Norman, and Ssewanyana Ernest. We also thank Ronald Olum for his support during data analysis. Specially, we thank Dr. Andrew Tagg (Emergency Physician, Western Health, Melbourne, Australia) for his contributions including copy editing of the study manuscript and provision of financial support for purchasing a license for using the Maslach Burnout Inventory instrument.

\section{Author Contributions}

All authors made a significant contribution to the work reported, be it in the conception, study design, execution, acquisition of data, analysis and interpretation, or in all these areas; took part in drafting, revising, or critically reviewing the article; gave final approval of the version to be published; have agreed on the journal to which the article has been submitted; and agree to be accountable for all aspects of the work.

\section{Funding}

This study was not funded.

\section{Disclosure}

The authors declare that they have no conflicts of interest for this work.

\section{References}

1. WHO. Burn-out an "occupational phenomenon": international classification of diseases [Internet]. WHO, World Health Organization; 2019 [cited September 19, 2020]. Available from: http://www.who. int/mental_health/evidence/burn-out/en/. Accessed December 30, 2020

2. Understanding the burnout experience: recent research and its implications for psychiatry - Maslach - 2016 - world psychiatry. Wiley Online Library; 2016 [cited October 7, 2020]. Available from: https://onlineli brary.wiley.com/doi/full/10.1002/wps.20311. Accessed December 30, 2020

3. Fares J, Al Tabosh H, Saadeddin Z, El Mouhayyar C, Aridi H. Stress, burnout and coping strategies in preclinical medical students. $N \mathrm{Am}$ J Med Sci. 2016;8(2):75-81. doi:10.4103/1947-2714.177299

4. Muzafar Y, Khan HH, Ashraf H, et al. Burnout and its associated factors in medical students of lahore, pakistan. Cureus. [cited September 19, 2020]. Available from: https://www.ncbi.nlm.nih. gov/pmc/articles/PMC4689594/. Accessed December 30, 2020.

5. Dyrbye LN, Thomas MR, Huntington JL, et al. Personal life events and medical student burnout: a multicenter study. Acad Med. 2006;81 (4):374-384. doi:10.1097/00001888-200604000-00010

6. Galán F, Sanmartín A, Polo J, Giner L. Burnout risk in medical students in Spain using the Maslach Burnout Inventory-Student Survey. Int Arch Occup Environ Health. 2011;84(4):453-459. doi:10.1007/s00420-011-0623-x

7. Atlam SA. Burnout syndrome: determinants and predictors among medical students of Tanta University, Egypt. Egypt J Community Med. 2018;36(01):61-73. doi:10.21608/ejcm.2018.6870

8. ElKholy MM, El-Sayed ET, Sedrak AS, Raouf NA. Prevalence and predictors of burnout syndrome among medical students of Cairo University. Egypt J Community Med. 2019;37(3):83-92. doi:10.21 608/ejcm.2019.43375

9. Melaku L, Mossie A, Negash A. Stress among medical students and its association with substance use and academic performance. J Biomed Educ. 2015;2015:1-9. doi:10.1155/2015/149509

10. Dyrbye L, Shanafelt T. A narrative review on burnout experienced by medical students and residents. Med Educ. 2016;50(1):132-149. doi:10.1111/medu. 12927

11. Frajerman A, Morvan Y, Krebs M-O, Gorwood P, Chaumette B. Burnout in medical students before residency: a systematic review and meta-analysis. Eur Psychiatry. 2019;55:36-42. doi:10.1016/j. eurpsy.2018.08.006

12. McManus IC, Keeling A, Paice E. Stress, burnout and doctors' attitudes to work are determined by personality and learning style: a twelve year longitudinal study of UK medical graduates. BMC Med. 2004;18(2):29. doi:10.1186/1741-7015-2-29 
13. Chang E, Eddins-Folensbee F, Coverdale J. Survey of the prevalence of burnout, stress, depression, and the use of supports by medical students at one school. Acad Psychiatry. 2012;36(3):177-182.

14. Vidhukumar K, Hamza M. Prevalence and correlates of burnout among undergraduate medical students - a cross-sectional survey. Indian J Psychol Med. 2020;42(2):122-127. doi:10.4103/IJPSYM. IJPSYM 19219

15. Chunming WM, Harrison R, MacIntyre R, Travaglia J, Balasooriya C. Burnout in medical students: a systematic review of experiences in Chinese medical schools. BMC Med Educ. 2017;17 (1):217. doi:10.1186/s12909-017-1064-3

16. Haile YG, Senkute AL, Alemu BT, Bedane DM, Kebede KB. Prevalence and associated factors of burnout among Debre Berhan University medical students: a cross-sectional study. BMC Med Educ. 2019;19(1):413. doi:10.1186/s12909-019-1864-8

17. Obregon M, Luo J, Shelton J, Blevins T, MacDowell M. Assessment of burnout in medical students using the Maslach Burnou Inventory-Student Survey: a cross-sectional data analysis [Internet]. In review; 2020 [cited Sep 17, 2020]. Available from: https://www researchsquare.com/article/rs-30445/v2. Accessed December 30, 2020.

18. Ef C, Sa S, At S, Ev M, Tm A. Burnout syndrome and associated factors among medical students: a cross-sectional study [Internet] vol. 67, clinics (Sao Paulo, Brazil). clinics (Sao Paulo); 2012 [cited Sep 16, 2020]. Available from: https://pubmed.ncbi.nlm.nih.gov/ 22760894/.

19. Características psicométricas do Maslach Burnout Inventory. Student Survey (MBI-SS) em estudantes universitários brasileiros. PsicoUSF. 2017;22(3):569. doi:10.1590/1413-82712017220315

20. Wickramasinghe ND, Dissanayake DS, Abeywardena GS. Clinical validity and diagnostic accuracy of the Maslach burnout inventory-student survey in Sri Lanka. Health Qual Life Outcomes. 2018;16(1):220. doi:10.1186/s12955-018-1048-y

21. Zeinab R, Reza AM, Ahmad B. The psychometric characteristics of Maslach Burnout Inventory Student Survey: a study students of Isfahan University. J Res Med Sci. 2014;16(9):55-58.

22. Boni RADS, Paiva CE, de Oliveira MA. Burnout among medical students during the first years of undergraduate school: prevalence and associated factors. PLoS One. 2018;13(3):e0191746. doi:10.13 71/journal.pone.0191746

23. Saadat H, Lin SL, Kain ZN. The role of "wellness" in medical education. Int Anesthesiol Clin. 2010;48(3):131-138. doi:10.1097/ AIA.0b013e3181e60213
24. Solanky P, Desai B, Kavishwar A, Kantharia S. Study of psychological stress among undergraduate medical students of government medical college, Surat. Int J Med Sci Public Health. 2012;1(2):38. doi:10.5455/ijmsph.2012.1.38-42

25. Njim T, Makebe H, Toukam L, et al. Burnout Syndrome amongst medical students in cameroon: a cross-sectional analysis of the determinants in preclinical and clinical students. J Psychiatry. 2019;2019: e4157574. doi:10.1155/2019/4157574

26. Drolet BC, Rodgers S. A comprehensive medical student wellness program-design and implementation at Vanderbilt School of Medicine. Acad Med. 2010;85(1):103-110. doi:10.1097/ACM.0b $013 \mathrm{e} 3181 \mathrm{c} 46963$

27. Redwood SK, Pollak MH. Student-led stress management program for first-year medical students. Teach Learn Med. 2007;19(1):42-46. doi:10.1080/10401330709336622

28. Wachholtz A, Rogoff M. The relationship between spirituality and burnout among medical students. J Contemp Med Educ. 2013;1 (2):83-91. doi:10.5455/jcme.20130104060612

29. Supporting medical students with mental health conditions [Internet]. [cited Oct 14, 2020]. Available from: https://www.gmc-uk.org/educa tion/standards-guidance-and-curricula/guidance/supporting-medicalstudents-with-mental-health-conditions.

30. Moir F, Yielder J, Dixon H. SAFE-DRS: 5 years of a health and wellbeing curriculum in the medical programme at the University of Auckland; 2018 [cited Nov 29, 2020]. Available from: https://research space.auckland.ac.nz/handle/2292/43095. Accessed December 30, 2020.

31. Hassed C, Sierpina VS, Kreitzer MJ. The health enhancement program at Monash University medical school. Explore. 2008;4 (6):394-397. doi:10.1016/j.explore.2008.09.008

32. Wild K, Scholz M, Ropohl A, Bräuer L, Paulsen F, Burger PHM. Strategies against burnout and anxiety in medical education - implementation and evaluation of a new course on relaxation techniques (Relacs) for medical students. PLoS One. 2014;9(12):e114967. doi:10.1371/journal.pone.0114967

33. Glenn D. Israel determining sample size [Internet]. University of Florida. Available from: https://www.tarleton.edu/academicassess ment/documents/samplesize.pdf. Accessed December 30, 2020.
Advances in Medical Education and Practice

\section{Publish your work in this journal}

Advances in Medical Education and Practice is an international, peerreviewed, open access journal that aims to present and publish research on Medical Education covering medical, dental, nursing and allied health care professional education. The journal covers undergraduate education, postgraduate training and continuing medical education including emerging trends and innovative models linking education, research, and health care services. The manuscript management system is completely online and includes a very quick and fair peer-review system. Visit http://www.dovepress.com/testimonials.php to read real quotes from published authors. 